\title{
ULTRAVIOLET-SPECTROPHOTOMETRIC METHOD DEVELOPMENT AND VALIDATION FOR THE DETERMINATION OF NORFLOXACIN PRESENT IN TASTE MASKED DRUG RESIN COMPLEX
}

\author{
AYYA RAJENDRA PRASAD*, JAYANTHI VIJAYA RATNA
}

Department of Pharmaceutical Technology, A.U. College of Pharmaceutical Sciences, Andhra University, Visakhapatnam, Andhra Pradesh, India. Email: dr.ayyarajendraprasad@gmaillcom

Received: 07 December 2017, Revised and Accepted: 05 January 2018

\section{ABSTRACT}

Objective: The objective of this study was developed and validated a novel, specific, precise, and simple ultraviolet (UV)-spectrophotometric method for the estimation of norfloxacin present in taste masked drug-resin complex.

Methods: UV-spectrophotometric determination was performed with ELICO SL 1500 UV-visible spectrophotometer using $0.1 \mathrm{~N} \mathrm{HCl} \mathrm{as} \mathrm{a} \mathrm{medium.} \mathrm{The}$ spectrum of the standard solution was run from 200 to $400 \mathrm{~nm}$ range for the determination of absorption maximum ( $\lambda$ max). $\lambda$ max of norfloxacin was found at $278 \mathrm{~nm}$. The absorbance of standard solutions of 1, 2, 3, 4, and $5 \mu \mathrm{g} / \mathrm{ml}$ of drug solution was measured at an absorption maximum at $278 \mathrm{~nm}$ against the blank. Then, a graph was plotted by taking concentration on X-axis and absorbance on Y-axis which gave a straight line. Validation parameters such as linearity and range, selectivity and specificity, limit of detection (LOD) and limit of quantification (LOQ), accuracy, precision, and robustness were evaluated as per the International Conference on Harmonization (ICH) guidelines.

Results: Linearity for the UV-spectrophotometric method was noted over a concentration range of $1-5 \mu \mathrm{g} / \mathrm{ml}$ with a correlation coefficient of 0.9995 . The LOD and LOQ for norfloxacin were found at $0.39 \mu \mathrm{g} / \mathrm{ml}$ and $1.19 \mu \mathrm{g} / \mathrm{ml}$, respectively. Accuracy was in between $99.00 \%$ and $99.17 \%$. $\%$ relative standard deviation for repeatability, intraday precision, and interday precision was found to be 0.600 , in between 0.291 and 0.410 , and in between 0.682 and 1.439 , respectively. The proposed UV spectrophotometric method is found to be robust.

Conclusion: The proposed UV-spectrophotometric method was validated according to the ICH guidelines, and results and statistical parameters demonstrated that the developed method is sensitive, precise, reliable, and simple for the estimation of norfloxacin present in taste masked drug-resin complex.

Keywords: Ultraviolet spectroscopy, Validation, Analytical method development, Norfloxacin, Indion 414, Indion 254, Drug resin complex, Resinate, $0.1 \mathrm{~N} \mathrm{HCl}$.

(c) 2018 The Authors. Published by Innovare Academic Sciences Pvt Ltd. This is an open access article under the CC BY license (http://creativecommons. org/licenses/by/4. 0/) DOI: http://dx.doi.org/10.22159/ajpcr.2018.v11i4.24155

\section{INTRODUCTION}

Norfloxacin is a synthetic chemotherapeutic antibacterial agent $[1,2]$. Norfloxacin is a broad-spectrum antibiotic that is active against both Gram-positive and Gram-negative bacteria. Chemically, it is 1-ethyl6-fluoro-4-oxo-7-piperazin-1-yl-1H quinoline-3-carboxylic acid. Norfloxacin is a white-to-pale yellow crystalline powder. It is freely soluble in glacial acetic acid and very slightly soluble in ethanol, methanol, and water [3]. It functions by inhibiting DNA gyrase, a type II topoisomerase, and topoisomerase IV [4], enzymes necessary to separate bacterial DNA, thereby inhibiting cell division. Although human cells do not contain DNA gyrase, they do contain a topoisomerase enzyme that functions in the same manner. This mammalian enzyme is not affected by bactericidal concentrations of quinolones. It is unclear how inhibition of DNA gyrase leads to bacterial cell death. Both rapid and slow-growing organisms are inhibited by fluoroquinolones. In addition, fluoroquinolones exhibit a prolonged post-antibiotic effect. Organisms may not resume growth for 2-6 h after exposure to norfloxacin, despite undetectable drug levels (Fig. 1).

Ailments such as typhoid fever caused by Salmonella typhi, uncomplicated urinary tract infection, including cystitis, due to Escherichia coli, Klebsiella pneumoniae, or Proteus mirabilis, and traveler's diarrhea are being treated with the usual doses of $15 \mathrm{mg} / \mathrm{kg} /$ day PO given in two divided doses for 5-7 days [5], 400 mg PO every 12 $\mathrm{h}$ for 3 days, and $400 \mathrm{mg}$ PO every $12 \mathrm{~h}$ up to 3 days [6], respectively. The penultimate doses are only for adults.
To treat bacterial conjunctivitis, the usual dose for adults and children is instill one drop of $0.3 \%$ solution in affected eye 4 times daily for up to 7 days. For severe infections, instill 1-2 drops every $2 \mathrm{~h}$ for the first day.

The literature survey reveals that various analytical methods have been developed such as high-performance liquid chromatography [7-10] and ultraviolet (UV) spectroscopy methods [11-15] for the estimation of norfloxacin present in bulk, single or combinational pharmaceutical formulations. Most of the reported methods are using several solvents, expensive reagents, and often time-consuming. Due to simplicity of UV spectrophotometry and also precise, reliable, minimum solvent usage, and requires less analysis time, it is widely used for the estimation of drug content in bulk and pharmaceutical products.

A detailed review of the literature regarding the existing methods revealed that there is a need for the development of the spectrophotometric method, which is simple for the estimation of norfloxacin present in taste masked drug-resin complex which are prepared by batch technique or column technique [16]. An effort was made in the present method to develop a simple, sensitive, accurate, reliable, and reproducible with minimum relative standard deviation (RSD) values for the estimation of norfloxacin present in taste masked drug-resin complex.

\section{MATERIALS AND METHODS}

Materials

Norfloxacin is gifted by Darvin private Laboratories Ltd., vijayawada. Indion 414 and Indion 254 were received as a gift sample from Ion 
Exchange India Limited. All other chemicals used were of analytical reagent grade.

\section{Equipment used}

Spectroscopic analysis was carried out using ELICO SL 1500 double-beam UV-visible spectrophotometer with $10 \mathrm{~mm}$ path length quartz cells was used for the analytical purpose.

Preparation of stock and standard solution for calibration curve For the method development, a stock solution of norfloxacin was prepared by dissolving $100 \mathrm{mg}$ of the drug in $100 \mathrm{ml}$ of $0.1 \mathrm{~N} \mathrm{HCl}$ so as to obtain a final concentration of $1 \mathrm{mg} / \mathrm{ml}$. From this stock solution, subsequent dilutions were made with $0.1 \mathrm{~N} \mathrm{HCl}$ to obtain the series of standard solutions containing $1,2,3,4$, and $5 \mu \mathrm{g} / \mathrm{ml}$ of solution. The spectrum of the standard solutions was run from 200 to $400 \mathrm{~nm}$ range for the determination of absorption maximum $(\lambda \max ) \cdot \lambda$ max of norfloxacin was found at $278 \mathrm{~nm}$. The absorbance of above dilutions was measured at $278 \mathrm{~nm}$ using $0.1 \mathrm{~N}$ $\mathrm{HCl}$ as a blank. A graph was plotted by taking concentration on X-axis and absorbance on Y-axis which gave a straight line.

\section{Analysis of norfloxacin in drug-resin complex}

Drug-resin complex equivalent to $100 \mathrm{mg}$ of norfloxacin was weighed accurately and was transferred into $100 \mathrm{ml}$ of volumetric flask. $100 \mathrm{ml}$ of $0.1 \mathrm{~N} \mathrm{HCl}$ was added to this volumetric flask and was stirred continuously for $1 \mathrm{~h}$ on a magnetic stirrer. After stirring, this solution was filtered through Whatman filter paper. Filtered sample was suitably diluted with $0.1 \mathrm{~N} \mathrm{HCl}$ and analyzed spectrophotometrically at $278 \mathrm{~nm}$ using the proposed method.

\section{Validation of developed analytical method}

This developed method for estimation of norfloxacin was validated as per the International Conference on Harmonization (ICH) guidelines [17].

\section{Linearity and range}

Linearity is the ability of a method to elicit test results that are directly proportional to the analyte concentration within a given range. The range is the interval between the upper and lower levels of analytes that have been demonstrated to be determined with precision, accuracy, and linearity using the method as described. 1, 2, 3, 4, and $5 \mu \mathrm{g} / \mathrm{ml}$ of standard solutions were selected for assessing linearity range. The calibration curve was plotted using concentration of the standard solution versus absorbance, and the regression equation was calculated. The least squares method was used to calculate the slope, intercept, and correlation coefficient.

\section{Selectivity and specificity}

The ability to measure accurately and specifically the analyte of interest in the presence of other components present in the drug-resin complex was analyzed. Placebo solution was prepared by adding Indion 414 and Indion 254. The standard, placebo, placebo along with analyte, and test preparations were analyzed as per the method to identify interference of placebo with the absorbance of norfloxacin.

\section{Detection and quantification limits}

Limit of detection (LOD) represents the lowest amount of analyte in the sample which can be detected. Limit of quantification (LOQ) represents the lowest amount of analyte, which can be quantitatively determined. LOD and LOQ are calculated based on the standard deviation of the response and the slope of the calibration curve.

$\mathrm{LOD}=3.3 \sigma / \mathrm{S}$

$\mathrm{LOQ}=10 \sigma / \mathrm{S}$

\section{Accuracy}

The accuracy of the proposed method was assessed by recovery studies at three different levels, i.e., $80 \%, 100 \%$, and $120 \%$. The recovery studies were carried out by adding a known amount of standard solution of norfloxacin to a pre-analyzed drug-resin

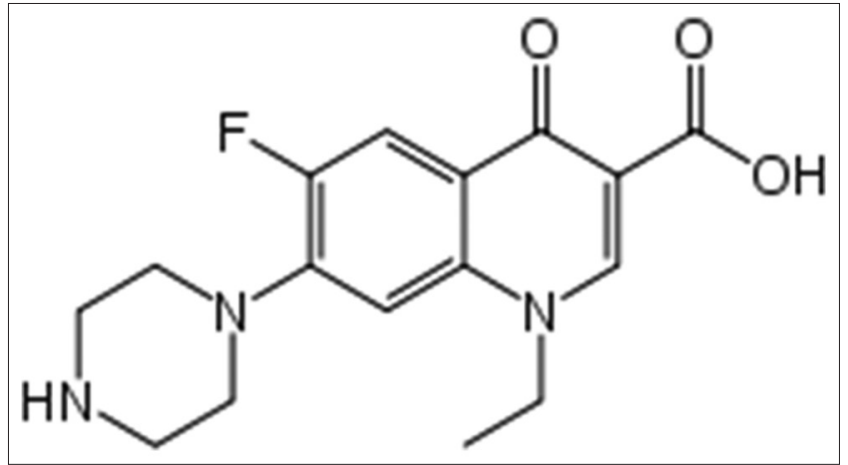

Fig. 1: Chemical structure of norfloxacin

complex solution. The resulting solutions were then reanalyzed by the proposed method. The total amount of drug found and percentage recovery was calculated.

\section{Precision}

The precision of the method was performed at three different levels: Repeatability, intraday precision, and interday precision at different concentration levels of analyte covering the concentration range. In repeatability, the absorbance of the $2 \mu \mathrm{g} / \mathrm{ml}$ norfloxacin concentration solution was measured 6 times and \% RSD was calculated. The intraday precision was performed by analyzing six replicate standard solutions on the same day, and interday precision was performed by analyzing a series of standard solutions for 3 consecutive days using the proposed UV-spectrophotometric method.

\section{Robustness}

The evaluation of robustness should be considered during the development phase and depends on the type of procedure deliberate variations in method parameters. If measurements are susceptible to variation in analytical conditions, the analytical condition should be suitably controlled or a precautionary statement should be included in the procedure. In this present work, absorption maxima were decreased and increased by $1 \mathrm{~nm}$ and the process was carried for $3 \mu \mathrm{g} / \mathrm{ml}$ standard solution. The $\%$ RSD was calculated.

\section{RESULTS AND DISCUSSION}

The proposed method was found to be simple, sensitive, accurate, precise, economical, and rapid for the estimation of norfloxacin present in drug-resin complex. The method was validated as per the ICH guidelines (Q2 R1).

\section{Linearity and range}

A linear correlation was found between absorbance at $\lambda_{\max }$ and concentration of norfloxacin. The graph is described by the regression equation: $\mathrm{Y}=\mathrm{a}+\mathrm{bX}$ (where $\mathrm{Y}=\mathrm{absorbance}$ of drug solution, $\mathrm{a}=$ intercept, $\mathrm{b}$ $=$ slope, and $\mathrm{X}=$ concentration of drug in $\mu \mathrm{g} / \mathrm{ml}$ ). The slope (b), intercept (a), and correlation coefficient (r) were evaluated using the method of least squares. Good linear correlations were obtained between absorbance and standard drug concentration in the selected range of $1-5 \mu \mathrm{g} / \mathrm{ml}$. Characteristic parameters such as slope is 0.126 , Y intercept is 0.014 , and correlation coefficient is 0.9995 (Fig. 2 and Table 1).

\section{Specificity in the presence of resins}

The selectivity and specificity of the proposed method was tested by studying the effect of resins used in the preparation of drug-resin complexes. In the analysis of placebo, the absorbance value was nearly the same as that for solvent suggesting the non-interference by the resins added to prepare the placebo solution.

\section{LOD and LOQ}

The LOD and LOQ of norfloxacin were determined using the standard deviation of the response and slope approach as defined in the 
ICH guidelines. The LOD and LOQ for norfloxacin were found to be $0.39 \mu \mathrm{g} / \mathrm{ml}$ and $1.19 \mu \mathrm{g} / \mathrm{ml}$, respectively, indicating that the proposed UV method is highly sensitive. Results of regression and analytical parameters are reported in Table 2.

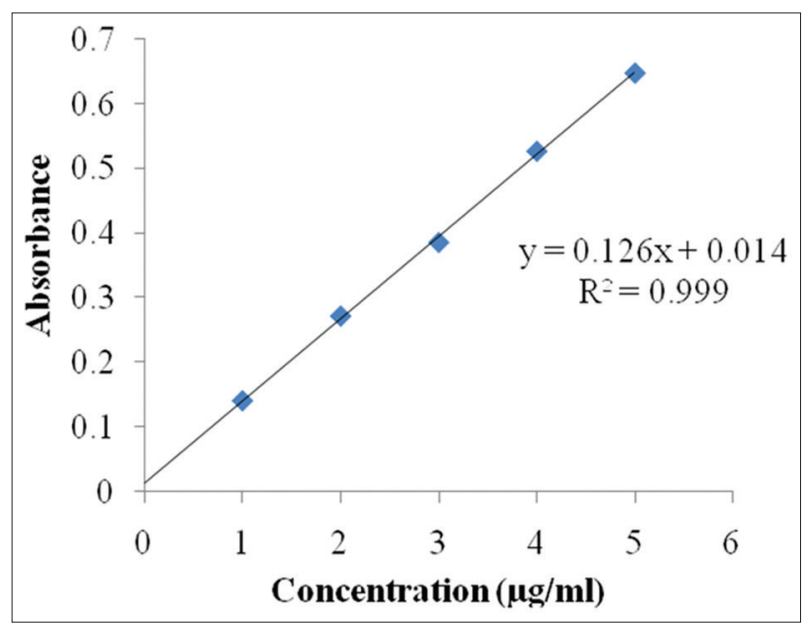

Fig. 2: Calibration curve of norfloxacin in $0.1 \mathrm{~N} \mathrm{HCl}$

Table 1: Calibration curve for the estimation of norfloxacin in $0.1 \mathrm{~N} \mathrm{HCl}$

\begin{tabular}{ll}
\hline Concentration $(\mu \mathrm{g} / \mathrm{ml})$ & Absorbance $\left(\operatorname{mean} \pm \mathrm{SD}^{*}\right)(\mathbf{n}=\mathbf{6})$ \\
\hline 1 & $0.141 \pm 0.007$ \\
2 & $0.272 \pm 0.002$ \\
3 & $0.386 \pm 0.003$ \\
4 & $0.527 \pm 0.003$ \\
5 & $0.648 \pm 0.005$ \\
\hline
\end{tabular}

Table 2: Regression and analytical parameters

\begin{tabular}{|c|c|}
\hline Parameter & Value \\
\hline$\lambda_{\text {max }}, \mathrm{nm}$ & 278 \\
\hline Beer's law limits $(\mu \mathrm{g} / \mathrm{ml})$ & $1-5$ \\
\hline Regression equation, $\mathrm{Y}^{*}$ & $Y=0.126 X+0.014$ \\
\hline Intercept, (a) & 0.014 \\
\hline Slope, (b) & 0.126 \\
\hline Correlation coefficient $(\mathrm{r})$ & 0.9995 \\
\hline Standard deviation of intercept & 0.014998 \\
\hline Limit of detection $(\mu \mathrm{g} / \mathrm{ml})$ & 0.39 \\
\hline Limit of quantification $(\mu \mathrm{g} / \mathrm{ml})$ & 1.19 \\
\hline
\end{tabular}

\section{Accuracy}

The accuracy of an analytical method is the closeness of test results to a true value. The accuracy of the method was evaluated by standard addition method at 3 levels. A standard quantity equivalent to $80 \%, 100 \%$, and $120 \%$ is to be added to the sample. Results within the range of $99.00-99.17 \%$ ensure an accurate method as well as indicate non-interference with the resins. Results of recovery studies are reported in Table 3.

\section{Precision}

$\%$ RSD for repeatability, intraday precision, and interday precision was found to be 0.600 , in between 0.291 and 0.410 , and in between 0.682 and 1.439, respectively. The results showed an excellent repeatability, intraday precision, and interday precision of the proposed method. The results obtained are presented in Tables 4-6.

Table 4: Repeatability studies

\begin{tabular}{llll}
\hline Concentration $(\mu \mathrm{g} / \mathrm{ml})$ & Absorbance & Mean $\pm \mathbf{S D}^{*}(\mathbf{n}=\mathbf{6})$ & \% RSD** \\
\hline 2 & 0.271 & $0.272 \pm 0.002$ & 0.600 \\
2 & 0.274 & & \\
2 & 0.272 & & \\
2 & 0.273 & & \\
2 & 0.274 & & \\
2 & 0.277 & & \\
\hline *SD: Standard deviation, ${ }^{* *}$ RSD: Relative standard deviation
\end{tabular}

Table 5: Intraday precision for five different concentrations of norfloxacin

\begin{tabular}{|c|c|c|c|c|}
\hline \multirow[t]{2}{*}{ Concentration $(\mu \mathrm{g} / \mathrm{ml})$} & \multicolumn{3}{|l|}{ Time } & \multirow[t]{2}{*}{$\% \mathrm{RSD}^{* *}$} \\
\hline & 10:30 a.m. & 1:0 p.m. & 4:30 p.m. & \\
\hline 1 & 0.141 & 0.141 & 0.140 & 0.410 \\
\hline 2 & 0.272 & 0.271 & 0.270 & 0.369 \\
\hline 3 & 0.386 & 0.384 & 0.383 & 0.397 \\
\hline 4 & 0.527 & 0.525 & 0.524 & 0.291 \\
\hline 5 & 0.648 & 0.646 & 0.643 & 0.390 \\
\hline
\end{tabular}

**RSD: Relative standard deviation

Table 6: Interday precision for five different concentrations of norfloxacin

\begin{tabular}{lllll}
\hline Concentration $(\mu \mathrm{g} / \mathrm{ml})$ & \multicolumn{2}{l}{ Day } & \multicolumn{2}{l}{$\%$} \\
\cline { 2 - 4 } & $\mathbf{1}$ & $\mathbf{2}$ & $\mathbf{3}$ & RSD $^{* *}$ \\
\hline 1 & 0.141 & 0.139 & 0.137 & 1.439 \\
2 & 0.272 & 0.269 & 0.266 & 1.115 \\
3 & 0.386 & 0.381 & 0.377 & 1.182 \\
4 & 0.527 & 0.521 & 0.516 & 0.682 \\
5 & 0.648 & 0.642 & 0.637 & 0.857 \\
\hline **RSD: Relative standard deviation & & & &
\end{tabular}

**RSD: Relative standard deviation

Table 3: Accuracy/recovery studies for three different concentrations of norfloxacin by the proposed method

\begin{tabular}{|c|c|c|c|c|c|}
\hline$\%$ Drug added & $\begin{array}{l}\text { Amount of drug added to } \\
\text { pre-analyzed sample }(\mu \mathrm{g} / \mathrm{ml})\end{array}$ & Amount found $(\mu \mathrm{g} / \mathrm{ml})$ & \% Recovery & $\begin{array}{l}\% \text { Average } \\
\text { recovery } \\
(n=3),\left(\text { mean } \pm S D^{*}\right)\end{array}$ & \% RSD** \\
\hline 80 & 2.4 & 2.37 & 98.75 & & \\
\hline 80 & 2.4 & 2.38 & 99.17 & & \\
\hline 100 & 3 & 2.96 & 98.67 & $99.00 \pm 0.333$ & 0.337 \\
\hline 100 & 3 & 2.97 & 99.00 & & \\
\hline 120 & 3.6 & 3.56 & 98.89 & $99.17 \pm 0.278$ & 0.280 \\
\hline 120 & 3.6 & 3.57 & 99.17 & & \\
\hline 120 & 3.6 & 3.58 & 99.44 & & \\
\hline
\end{tabular}

*SD: Standard deviation, ${ }^{* *}$ RSD: Relative standard deviation 
Table 7: Effect of different wavelengths of light on a $3 \mu \mathrm{g} / \mathrm{ml}$ solution of norfloxacin in $0.1 \mathrm{~N} \mathrm{HCl}$

\begin{tabular}{|c|c|c|c|c|}
\hline Wavelength (nm) & Concentration $(\mu \mathrm{g} / \mathrm{ml})$ & Absorbance & $\operatorname{Mean} \pm \operatorname{SD}^{*}(n=3)$ & \%RSD** \\
\hline \multirow[t]{3}{*}{277} & 3 & 0.383 & $0.382 \pm 0.001$ & 0.262 \\
\hline & & 0.381 & & \\
\hline & & 0.382 & & \\
\hline \multirow[t]{3}{*}{278} & 3 & 0.385 & $0.386 \pm 0.001$ & 0.259 \\
\hline & & 0.387 & & \\
\hline & & 0.386 & & \\
\hline \multirow[t]{2}{*}{279} & 3 & 0.381 & $0.381 \pm 0.001$ & 0.151 \\
\hline & & 0.381 & & \\
\hline
\end{tabular}

*SD: Standard deviation, ${ }^{* *}$ RSD: Relative standard deviation

\section{Robustness}

The robustness of this method was tested in terms of variation in wavelength change. Experimental findings proved that the change since $\%$ RSD values were found to be $<0.4 \%$ (less than the acceptable theoretical limit of $<2 \%$ RSD). The proposed UV-spectrophotometric method was found to be robust. The results obtained are presented in Table 7.

\section{CONCLUSION}

This developed method is found to be specific as there was no interference of any resin present in taste masked drug-resin complex in the analysis of norfloxacin. The results and the statistical parameters demonstrated that the proposed UV spectrophotometric method is simple, rapid, reliable, accurate, and precise. Hence, it can be used conveniently for the determination of drug present in taste masked drug-resin complex.

\section{ACKNOWLEDGMENTS}

The authors like to acknowledge the staff and management of the KVSR Siddhartha College of pharmaceutical sciences, Vijayawada, Andhra Pradesh, India, for providing necessary facilities to carry out the research work.

\section{AUTHOR CONTRIBUTIONS}

The author, Ayya Rajendra Prasad is a Ph. D. student of Dr. Smt. Jayanthi Vijaya Ratna. The work relates to Ph. D. work of author under the guidance of Dr. Smt. Jayanthi Vijaya Ratna.

\section{CONFLICTS OF INTERESTS}

The authors confirm that this article content has no conflict of interest.

\section{REFERENCES}

1. Nelson JM, Chiller TM, Powers JH, Angulo FJ. Fluoroquinoloneresistant Campylobacter species and the withdrawal of fluoroquinolones from use in poultry: A public health success story. Clin Infect Dis 2007;7:977-80.

2. Padeĭskaia EN. Norfloxacin: More than 20 years of clinical use, the results and place among fluoroquinolones in modern chemotherapy for infections. Antibiot Khimioter 2003;9:28-36.

3. Available from: https://www.dailymed.nlm.nih.gov/dailymed/archives/ fdaDrugInfo.cfm?archiveid=8108.

4. Drlica K, Zhao X. DNA gyrase, topoisomerase IV, and the 4-quinolones. Microbiol Mol Biol Rev 1997;3:377-92.

5. Bhutta ZA. Current concepts in the diagnosis and treatment of typhoid fever. BMJ 2006;333:78-82.

6. DuPont HL, Ericsson CD. Prevention and treatment of traveler's diarrhea. N Engl J Med 1993;328:1821-6.

7. Borrego MC, Diaz MC, Dia DC. Validation of a high - Performance liquid chromatographic method for the determination of norfloxacin and its application to stability studies (photo-stability study of norfloxacin). J Pharm Biomed Anal 1999;6:919-26.

8. Lagana A, Marino A, Rotatori M, Curini R, D’Ascenzo G, Miano L. High-performance liquid chromatographic analysis of norfloxacin in human tissues and plasma with fluorescence detection. J Pharm Biomed Anal 1988;3:221-8.

9. Mascher HJ, Kikuta C. Determination of norfloxacin in human plasma and urine by high-performance liquid chromatography and fluorescence detection. J Chromatogr A 1998;2:381-5.

10. Lagana A, Curini R, D’Ascenzo G, Marino A, Rotatori M. Highperformance liquid chromatographic determination of norfloxacin in human tissues and plasma with fluorescence detection. J Chromatogr B Biomed Sci Appl 1987;417:135-42.

11. Rahman N, Ahmad Y, Azmi SN. Kinetic spectrophotometric method for the determination of norfloxacin in pharmaceutical formulations. Eur $\mathrm{J}$ Pharm Biopharm 2004;2:359-67.

12. Darwish IA, Sultan MA, Al-Arfaj HA. Novel selective kinetic spectrophotometric method for determination of norfloxacin in its pharmaceutical formulations. Talanta 2009;5:1383-8.

13. El Walily AF, Belal SF, Bakry RS. Spectrophotometric and spectrofluorimetric estimation of ciprofloxacin and norfloxacin by ternary complex formation with eosin and palladium (II). J Pharm Biomed Anal 1996;5:561-9.

14. El Brashy AM, Metwally ME, El Sepai FA. Spectrophotometric determination of some fluoroquinolone antibacterials by binary complex formation with xanthenes dyes. Farmaco 2004;10:809-17.

15. Girishpai K, Divya S, Reddy MS, Kumar L, Krishna TV. Solubility enhancement of norfloxacin by hydrotropy technique. Int J Pharm Pharm Sci 2014;8:395-7.

16. Sanghavi NM. Ion-exchange resins as matrices for controlled drug release. Indian Drugs 1988;26:27-32.

17. Validation of Analytical Procedures. Text and Methodology. Geneva, Switzerland: International Conference on Harmonization (ICH) Q2 (R1) Guideline; 2005. 